\title{
Domestic Innovation and International Technology Diffusion as Sources of Comparative Advantage
}

\author{
Ana Maria Santacreu and Heting Zhu
}

\begin{abstract}
Productivity differences across countries determine patterns of international trade-hence, comparative advantage. We use a multi-industry model of international trade to estimate a measure of industry productivity. We then quantify the effect that domestic innovation and technology diffusion have in explaining differences in productivity across countries and industries. Consistent with standard growth theories, we find the following: (i) Higher-income countries benefit more from domestic innovation than lower-income countries, whereas lower-income countries benefit more from technology diffusion; and (ii) the speed of convergence is larger for those countries and industries that are farther away from the technology frontier. To the extent that productivity differences determine comparative advantage, our findings suggest that domestic innovation and technology diffusion are endogenous sources of comparative advantage. (JEL F12, O33, O41, O47)
\end{abstract}

Federal Reserve Bank of St. Louis Review, Fourth Quarter 2018, 100(4), pp. 317-35.

https://doi.org/10.20955/r.100.317-35

\section{INTRODUCTION}

In the Ricardian model of trade, productivity differences across countries and industries determine the patterns of international trade-hence, comparative advantage (Costinot et al., 2012). As productivity differences increase over time, comparative advantage strengthens. Standard models of trade take these productivity differences, and therefore comparative advantage forces, as given (Eaton and Kortum, 2002, and Caliendo and Parro, 2015). However, understanding the determinants of comparative advantage is important in analyzing welfare gains from trade. Recently, several articles have studied endogenous forces that may cause differences in productivity across countries and industries (Sampson, 2017, Somale, 2017, and Cai et al., 2017). In these studies, innovation and its international diffusion across countries and industries are the main sources of differences in productivity. Countries and industries differ in both their ability to do research and development (R\&D) and their ability to adopt innovations that have been developed elsewhere (i.e., international technology diffusion).

Ana Maria Santacreu is an economist and Heting Zhu was a senior research associate at the Federal Reserve Bank of St. Louis.

( ) 2018, Federal Reserve Bank of St. Louis. The views expressed in this article are those of the author(s) and do not necessarily reflect the views of the Federal Reserve System, the Board of Governors, or the regional Federal Reserve Banks. Articles may be reprinted, reproduced, published, distributed, displayed, and transmitted in their entirety if copyright notice, author name(s), and full citation are included. Abstracts, synopses, and other derivative works may be made only with prior written permission of the Federal Reserve Bank of St. Louis. 


\section{Santacreu and Zhu}

Productivity evolves endogenously because of these two channels. Therefore, differences in the rate at which countries and industries innovate and adopt foreign technologies determine differences in relative productivity and comparative advantage.

We quantify the role of these two sources of productivity. We start by estimating industry productivity from a Ricardian model of trade à la Eaton and Kortum (2002). We follow the methodology developed by Levchenko and Zhang (2016) and adapted by Cai et al. (2017) and use data on bilateral trade flows for 43 countries ( 42 countries plus the rest of the world) and 20 industries to estimate a time series of industry productivity for 2000-14. We find the following: (i) There is a large dispersion in relative productivity at the country and industry level; (ii) the United States appears to be, albeit with a few exceptions, the country with the largest level of technology across all industries-hence, we treat it as the technology frontier; (iii) productivity at the country and industry level has been growing over time; but also (iv) not all countries and industries are converging to the technology frontier with the same intensity. This has implications for comparative advantage and welfare. As countries and industries converge to the technology frontier, comparative advantage and the gains from trade weaken. Conversely, if countries and industries become more dissimilar from the technology frontier, comparative advantage strengthens and the welfare gains from trade are larger.

We then explore, quantitatively, the role of innovation and international technology diffusion as endogenous sources of country-industry productivity and comparative advantage. We proceed by conducting two exercises. First, we regress the estimated annual productivity growth for each country-industry on a measure of domestic innovation and a measure of technology adoption at the country and industry level. We follow Proudman and Redding (2000) and quantify domestic innovation activity within each country-industry with data on total business R\&D spending. To measure the potential for technology adoption, we use the gap in the level of technology between each country-industry in the sample and the technology frontier in the initial period, which in our analysis is the year 2000. We find that, when we use the entire sample of countries, both domestic innovation and technology adoption have a positive and statistically significant effect on productivity growth. We then split the sample of countries into lower-income and higher-income countries and conduct the same regression analysis on the two groups. Our findings suggest that, in lower-income countries, the effect of domestic innovation on productivity growth is lower than that in higher-income countries. In particular, a 1 percent increase in the log of $R \& D$ spending implies a 0.21 percent increase in productivity growth in lower-income countries and a 0.49 percent increase in productivity in higher-income countries. Furthermore, the relative importance of innovation with respect to technology adoption is larger in higher-income countries than in lower-income countries. In a second exercise, we compute a measure of the speed of convergence of a country-industry to the technology frontier. We then regress the speed of convergence on the following: (i) the ratio of $R \& D$ spending of that country-industry relative to the R\&D spending of that industry in the United States (i.e., the technology frontier) and (ii) the potential for technology adoption as computed in the first exercise. We find that both variables have a positive and statistically significant effect on the speed of convergence. That is, countries and industries that spend more in $\mathrm{R} \& \mathrm{D}$ relative to the United States are closer to the frontier, and countries that start 
from a relatively more backward position converge to the technology frontier faster. This is consistent with standard theories of economic growth (see Grossman and Helpman, 1991a, Grossman and Helpman, 1991b, Rivera-Batiz and Romer, 1991, and Barro and Sala-i-Martin, 1997). Our approach is different from those articles and focuses on productivity at the industry level. To derive that measure, we use information from international trade variables. Our results indicate that domestic innovation and international technology diffusion are key determinants of country-industry productivity and, hence, endogenous sources of comparative advantage.

The rest of the article is organized as follows. Section 2 presents the methodology used to estimate relative productivity from trade data and then reports the quantitative results. Section 3 quantifies the role of innovation and international technology diffusion. Section 4 concludes.

\section{ESTIMATING COMPARATIVE ADVANTAGE AND RELATIVE PRODUCTIVITY}

In this section, we describe the methodology used to estimate the relative productivity of a country-industry at a point in time. Differences in productivity determine the patterns of trade and, hence, comparative advantage. We start by obtaining an expression for bilateral trade shares as a function of technology level, trade costs, and production costs. This expression delivers a theoretical gravity equation. Then we estimate the gravity equation and use the structure of the model to obtain our measure of relative productivity. Finally, we characterize the patterns of our estimated productivity along the cross-section as well as in its evolution over time.

\subsection{The Model}

Our model follows closely the production and international trade structure of Caliendo and Parro (2015) and Cai et al. (2017). It is a general equilibrium model of trade in intermediate goods, with industry heterogeneity and input-output linkages. The model builds upon the Ricardian trade model of Eaton and Kortum (2002) with multiple industries.

There are $M$ countries and $J$ industries. Countries are denoted by $i$ and $n$ and industries are denoted by $j$ and $k$. Labor is the only factor of production, and we assume it to be mobile across industries within a country but immobile across countries. In each country, there is a representative consumer who consumes a non-traded final good and saves. A perfectly competitive final producer combines the composite output of each J industry in the domestic economy with a Cobb-Douglas production function. In each industry there is a producer of a composite good that operates under perfect competition and that sells the good to the final producer and to intermediate producers from all industries in that country. Intermediate producers are monopolistic competitive firms that use labor and composite goods of every other industry in that country to produce varieties that are traded and used by the composite producer of that industry, either domestic or foreign. These firms are heterogeneous in their productivity. Trade is balanced period by period. 
Final Production. Domestic final producers use the composite output from each domestic industry $j$ in country $n$ at time $t, Y_{n t}^{j}$, to produce a non-traded final output $Y_{n t}$ according to the following Cobb-Douglas production function:

$$
Y_{n t}=\prod_{j=1}^{J}\left(Y_{n t}^{j}\right)^{\alpha^{j}},
$$

with $\alpha^{j} \in(0,1)$, the share of industry production on total final output, and $\sum_{j=1}^{J} \alpha^{j}=1$.

Final producers operate under perfect competition. Their profits are given by

$$
\Pi_{n t}=P_{n t} Y_{n t}-\sum_{j=1}^{J} P_{n t}^{j} Y_{n t}^{j},
$$

where $p_{n t}$ is the price of the final product and $p_{n t}^{j}$ is the price of the composite good produced in industry $j$ from country $n$.

Under perfect competition, the price charged by the final producer to the consumers is equal to the marginal cost; that is,

$$
P_{n t}=\prod_{j=1}^{J}\left(\frac{P_{n t}^{j}}{\alpha^{j}}\right)^{\alpha^{j}} .
$$

The demand by final producers for the industry composite good is given by

$$
Y_{n t}^{j}=\alpha^{j} \frac{P_{n t}}{P_{n t}^{j}} Y_{n t} .
$$

Intermediate Producers. In each industry $j$ there is a continuum of intermediate producers indexed by $\omega \in[0,1]$ that use labor, $l_{n t}^{j}(\omega)$, and a composite intermediate good from every other industry $k$ in the country, $m_{n t}^{j k}(\omega)$, to produce a variety $\omega$ according to the following constant returns to scale technology $\stackrel{1}{\text { : }}$

$$
q_{n t}^{j}(\omega)=z_{n}^{j}(\omega)\left[l_{n t}^{j}(\omega)\right]^{\gamma^{j}} \prod_{k=1}^{J}\left[m_{n t}^{j k}(\omega)\right]^{\gamma^{j k}}
$$

with $\gamma^{j}+\sum_{k=1}^{J} \gamma^{j k}=1$. Here, $\gamma^{j k}$ is the share of materials from industry $k$ used in the production of intermediate $\omega$ in industry $j$, and $\gamma^{j}$ is the share of value added. Firms are heterogeneous in their productivity $z_{n}^{j}(\omega)$.

The cost of producing each intermediate good $\omega$ is

$$
c_{n t}^{j}(\omega)=\frac{c_{n t}^{j}}{z_{n t}^{j}(\omega)},
$$

where $c_{n}^{j}$ denotes the cost of the input bundle. We have constant returns to scale,

$$
c_{n t}^{j}=\mathbf{\Upsilon}^{j} W_{n t}^{\gamma^{j}} \prod_{k=1}^{J}\left(P_{n t}^{k}\right)^{\gamma^{j k}},
$$

with $\Upsilon^{j}=\prod_{k=1}^{J}\left(\gamma^{j k}\right)^{-\gamma^{j k}}\left(\gamma^{j}\right)^{-\gamma^{j}}$ and $W_{n t}$ as the nominal wage rate.

Composite Intermediate Goods (Materials). Each industry $j$ produces a composite good combining domestic and foreign varieties from that industry. Composite producers operate under perfect competition and buy intermediate products $\omega$ from the lowest-cost supplier. 
The production for a composite good in industry $j$ and country $n$ is given by the Ethier (1982) constant elasticity of substitution function,

$$
Q_{n t}^{j}=\left(\int r_{n t}^{j}(\omega)^{1-1 / \sigma} d \omega\right)^{\sigma /(\sigma-1)}
$$

where $\sigma>0$ is the elasticity of substitution across intermediate goods and $r_{n t}^{j}(\omega)$ is the demand of intermediate goods from the lowest-cost supplier in industry $j$.

The demand for each intermediate good $\omega$ is given by

$$
r_{n t}^{j}(\omega)=\left(\frac{p_{n t}^{j}(\omega)}{P_{n t}^{j}}\right)^{-\sigma} Q_{n t}^{j},
$$

where

$$
P_{n t}^{j}=\left(\int p_{n t}^{j}(\omega)^{1-\sigma} d \omega\right)^{\frac{1}{1-\sigma}} .
$$

Composite intermediate goods are used as final goods in the final production and as materials for the production of the intermediate goods:

$$
Q_{n t}^{j}=Y_{n t}^{j}+\sum_{k=1}^{J} \int m_{n t}^{k j}(\omega) d \omega .
$$

International Trade. Trade in goods is costly. In particular, there are iceberg transport costs from shipping a good that is produced in industry $j$ from country $i$ to country $n, d_{n i}^{j}>1$.

Ricardian motives for trade are introduced as in Eaton and Kortum (2002) because productivity is allowed to vary by country-industry. The productivity of producing intermediate $\operatorname{good} \omega$ in country $i$ and industry $j$ is drawn from a Frechet distribution with parameter $T_{i}^{j}$ and shape parameter $\theta$. A higher $T_{i}^{j}$ implies a higher average productivity of that countryindustry, while a lower $\theta$ implies more dispersion of productivity across varieties:

$$
F\left(z_{i}^{j}\right)=\operatorname{Pr}\left[Z \leq z_{i}^{j}\right]=e^{-T_{i i}^{j} z^{-\theta}} .
$$

Prices of goods in industry $j$ in country $n$ can be expressed as

$$
P_{n t}^{j}=B\left(\Phi_{n t}^{j}\right)^{-1 / \theta}
$$

with $B=\left[\Gamma\left(\frac{\theta+1-\sigma}{\theta}\right)\right]^{1 /(1-\sigma)} ;$ and, in each country $n$ and industry $j$, accumulated technology, $\Phi_{n t}^{j}$, can be expressed as

$$
\Phi_{n t}^{j}=\sum_{i=1}^{M} T_{i t}^{j}\left(d_{n i}^{j} c_{i t}^{j}\right)^{-\theta}
$$

Here, $c_{i t}^{j}$ is the unit cost of producing an intermediate good in industry $j$ and country $i$. For prices to be well defined, we assume $\sigma<(1+\theta)$.

Expenditure Shares. The probability that country $i$ is the lowest-cost supplier of a good in industry $j$ to be exported to country $n$ is 


$$
\pi_{n i, t}^{j}=\frac{T_{i t}^{j}\left(c_{i t}^{j} d_{n i}^{j}\right)^{-\theta}}{\Phi_{n t}^{j}}
$$

where $\pi_{n i, t}^{j}$ is also the fraction of goods that industry $j$ in country $i$ sells to any industry in country $n$. In particular, the share that country $n$ spends on industry $j$ products from country $i$ is

$$
\pi_{n i t}^{j}=\frac{X_{n i t}^{j}}{X_{n t}^{j}}
$$

\subsection{The Methodology: Estimating the Gravity Equation}

To compute the productivity level for each country, industry, and period of time, we follow exactly the procedure developed in Cai et al. (2017) and estimate gravity equations for each industry and each period $t$. We start from the trade shares in equation (9):

$$
\pi_{n i}^{j}=\frac{X_{n i}^{j}}{X_{n}^{j}}=\frac{T_{i}^{j}\left(c_{i}^{j} d_{n i}^{j}\right)^{-\theta}}{\Phi_{n}^{j}} .
$$

Dividing the trade shares by their domestic counterpart as in Eaton and Kortum (2002) and assuming $d_{n n}^{j}=1$, we have

$$
\frac{\pi_{n i}^{j}}{\pi_{n n}^{j}}=\frac{X_{n i}^{j}}{X_{n n}^{j}}=\frac{T_{i}^{j}\left(c_{i}^{j} d_{n i}^{j}\right)^{-\theta}}{T_{n}^{j}\left(c_{n}^{j}\right)^{-\theta}} .
$$

Taking logs of both sides, we have

$$
\log \left(\frac{X_{n i}^{j}}{X_{n n}^{j}}\right)=\log \left(T_{i}^{j}\left(c_{i}^{j}\right)^{-\theta}\right)-\log \left(T_{n}^{j}\left(c_{n}^{j}\right)^{-\theta}\right)-\theta \log \left(d_{n i}^{j}\right) .
$$

The log of the trade costs can be expressed as

$$
\log \left(d_{n i}^{j}\right)=D_{n i, k}^{j}+B_{n i}+C L_{n i}+C O L_{n i}+e x_{i}^{j}+v_{n i}^{j} .
$$

Following Eaton and Kortum (2002), $D_{n i, k}^{j}$ is the contribution to trade costs of the distance between country $n$ and $i$ falling into the $k$ th interval (in miles), defined as $[0,350]$, [350, 750], $[750,1,500],[1,500,3,000],[3,000,6,000],[6,000$, maximum]. The other control variables between country $n$ and country $i$ include common border effect $B_{n i}$, common official language effect $C L_{n i}$, and colonial relationship effect $C O L_{n i}$. We include an exporter fixed effect, $e x_{i}^{j}$, to fit the patterns in both country incomes and observed price levels as shown in Waugh (2010). The error term is $v_{n i}^{j}$.

Substituting (13) back into (12) results in the following gravity equation at the industry level:

$$
\log \left(\frac{X_{n i}^{j}}{X_{n n}^{j}}\right)=\log \left(T_{i}^{j}\left(c_{i}^{j}\right)^{-\theta}\right)-\theta e x_{i}^{j}-\log \left(T_{n}^{j}\left(c_{n}^{j}\right)^{-\theta}\right)-\theta\left(D_{n i, k}^{j}+B_{n i}^{j}+C L_{n i}^{j}+C O L_{n i}^{j}+v_{n i}^{j}\right)
$$


Defining $\hat{F}_{i}^{j}=\log \left(T_{i}^{j}\left(c_{i}^{j}\right)^{-\theta}\right)-\theta e x_{i}^{j}$ and $F_{n}^{j}=\log \left(T_{n}^{j}\left(c_{n}^{j}\right)^{-\theta}\right)$, we then estimate the following equation using fixed effects and observables related to trade barriers, taking $\theta$ as known:

$$
\log \left(\frac{X_{n i}^{j}}{X_{n n}^{j}}\right)=\hat{F}_{i}^{j}-F_{n}^{j}-\theta\left(D_{n i, k}^{j}+B_{n i}^{j}+C L_{n i}^{j}+C O L_{n i}^{j}+v_{n i}^{j}\right) .
$$

Using the estimates of equation (15), we can back out $\log \left(d_{n i}^{j}\right)$ based on equation (13). To obtain the exporter fixed effect in trade cost, $e x_{i}^{j}$, we use the importer and exporter fixed effects from the gravity equation (15). That is, $e x_{i}^{j}=\left(F_{i}^{j}-\hat{F}_{i}^{j}\right) / \theta$.

The productivity of industry $j$ in country $n$ relative to that industry in the United States, $T_{n}^{j} / T_{U S}^{j}$, is then recovered from the estimated importer fixed effects as

$$
S_{n}^{j}=\frac{\exp \left(F_{n}^{j}\right)}{\exp \left(F_{U S}^{j}\right)}=\frac{T_{n}^{j}}{T_{U S}^{j}}\left(\frac{c_{n}^{j}}{c_{U S}^{j}}\right)^{-\theta},
$$

in which the relative cost component can be computed by expressing (3) as

$$
\frac{c_{n}^{j}}{c_{U S}^{j}}=\left(\frac{W_{n}}{W_{U S}}\right)^{\gamma^{j}} \prod_{k=1}^{J}\left(\frac{P_{n}^{k}}{P_{U S}^{k}}\right)^{\gamma^{j k}} .
$$

Using data on wages (in USD), estimates of price levels in each industry relative to that industry in the United States, we can back out the relative cost. To compute the relative price of each industry, we combine (6), (8), and (9) and get the following expression for relative prices:

$$
\frac{P_{n}^{j}}{P_{U S}^{j}}=\left(\frac{X_{n n}^{j} / X_{n}^{j}}{X_{U S U S}^{j} / X_{U S}^{j}} \frac{1}{S_{n}^{j}}\right)^{\frac{1}{\theta}} .
$$

The right-hand side of this expression can be estimated using the observed expenditure shares of domestic product in country $n$ and in the United States, as well as the estimated importer fixed effects. Substituting the estimates for relative prices and wages in each country-industry and using the estimated $S_{n}^{j}$, we can construct the relative productivity $T_{n}^{j} / T_{U S}^{j}$ based on equation (16).

We have now estimated the relative productivity in every industry for all countries with respect to the United States. To estimate the absolute level of productivity of country $n$ and industry $j$, we need the U.S. productivity level in that industry. First, using Organisation for Economic Co-operation and Development (OECD) industry account data, we estimate empirical productivity for each U.S. industry by the Solow residual (without capital in the production function):

$$
\ln Z_{U S}^{j}=\ln Y_{U S}^{j}-\gamma^{j} \ln L_{U S}^{j}-\sum_{k=1}^{J} \gamma^{j k} \ln M_{U S, j}^{j k}=1,2, \ldots, J,
$$

where $Z_{U S}^{j}$ is measured U.S. productivity in industry $j, Y_{U S}^{j}$ is the output, $L_{U S}^{j}$ is the labor input, and $M_{U S}^{j k}$ is the intermediate input from industry $k$. Finicelli et al. (2013) show that trade and 


\section{Santacreu and Zhu}

competition introduce selection in the productivity level, and the relationship between empirical productivity and the level of technology $T_{U S}^{j}$ in an open economy is given by

$$
T_{U S}^{j}=\left(Z_{U S}^{j}\right)^{\theta}\left[1+\sum_{i \neq U S} S_{i}^{j}\left(d_{U S, i}^{j}\right)^{-\theta}\right]^{-1},
$$

in which $S_{i}^{j}$ and $d_{U S, i}^{j}$ are estimated using (16) and (13), respectively. Finally, we express all $T_{U S}^{j}$ relative to $T_{U S}^{J}$ as

$$
\hat{T}_{U S}^{j}=\left(\frac{Z_{U S}^{j}}{Z_{U S}^{J}}\right)^{\theta}\left[1+\sum_{i \neq U S} S_{i}^{j}\left(d_{U S, i}^{j}\right)^{-\theta}\right]^{-1} .
$$

\subsection{Quantitative Results}

Using bilateral trade data and geography variables for a sample of 43 countries ( 42 countries plus the rest of the world), 20 industries, and the period 2000-14, we estimate the gravity regression in equation (15) for each time period and each industry. $\stackrel{2}{2}$ From the gravity regression, we first obtain estimates for exporter and importer fixed effects, $S_{i t}^{j}$ and $S_{n t}^{j}$, and the trade barriers, $d_{n i, t}^{j}$.

From our estimates of fixed effects and trade barriers, we use the equations of the model to back out $T_{n t}^{j} / T_{U S, t}^{j}$, which is a measure of average productivity for each country $n$ and industry $j$ relative to that same industry in the United States and can be used to analyze comparative advantage (see Levchenko and Zhang, 2016, and Sampson, 2017). We obtain a value of this measure for each period of time so that we can characterize it both in the cross-section as well as in its evolution over time.

We observe that the United States is the most productive country in every industry, with a few exceptions: For instance, Spain is more productive than the United States in the furniture and the food, beverages, and tobacco manufacturing industries; Norway is more productive in the wood and cork industry; and Luxembourg appears more productive than the United States in the pharmaceutical products industry. However, in 95 percent of the cases, the United States is the most productive country in all industries; hence, we will treat it as the technology frontier.

The distribution of $\log \left(T_{n}^{j}\right)$ for the years 2003 and 2012 is plotted in Figure 1. We observe that there is a lot of heterogeneity in productivity across countries and industries and that the distribution has shifted over time. Most countries and industries have experienced an increase in their productivity. In particular, the highest increases in average productivity are found in the computer, electronic, and optical products industry in China, Romania, and Indonesia. On the other hand, we observe decreases in average productivity in the textiles, apparel, and leather industry in France and in the machinery and equipment and the electrical equipment industries in Mexico.

The countries with the highest average productivity growth rates are Romania, Indonesia, and China, whereas average productivity growth rates have been decreasing in Mexico, Turkey, and Luxembourg (Figure 2). 
Figure 1

Kernel Density of Productivity

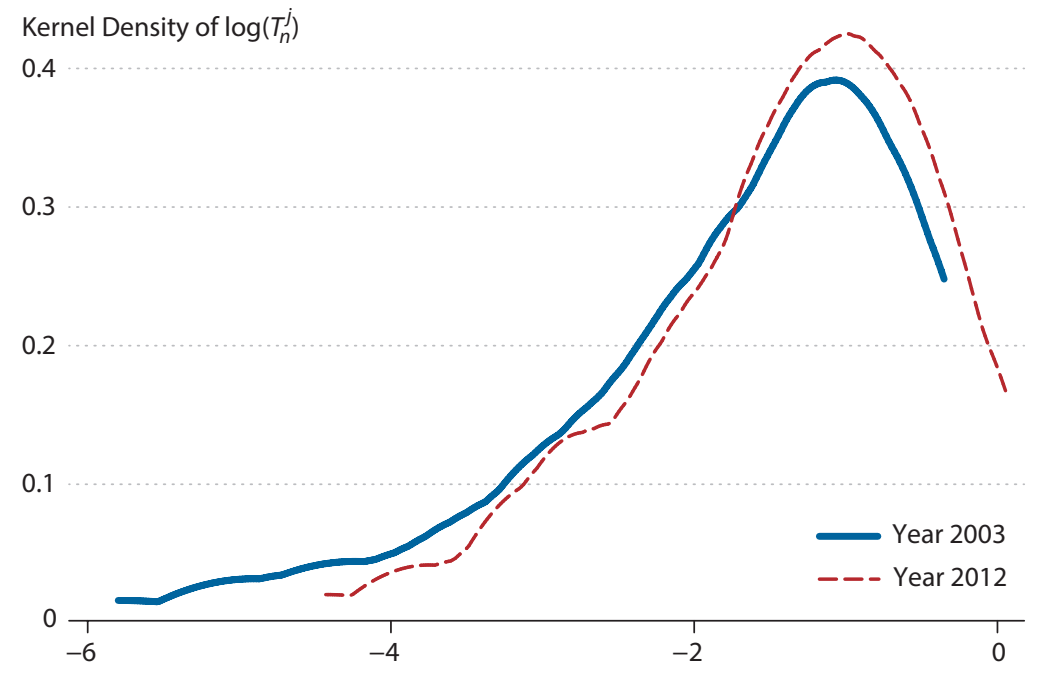

Figure 2

Growth Rate of Productivity, by Country

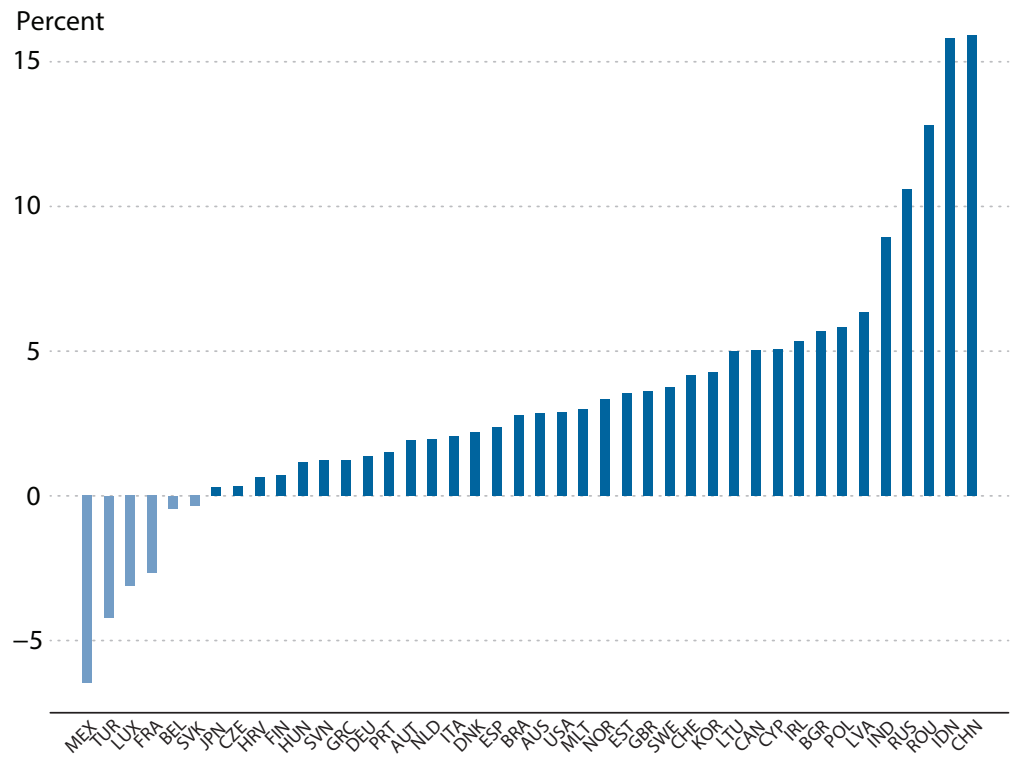

NOTE: Figure reports data for 42 countries (excluding rest of the world [ROW]), averaged across 20 industries, for 2000-14. 


\section{Figure 3}

\section{Growth Rate of Productivity, by Industry}

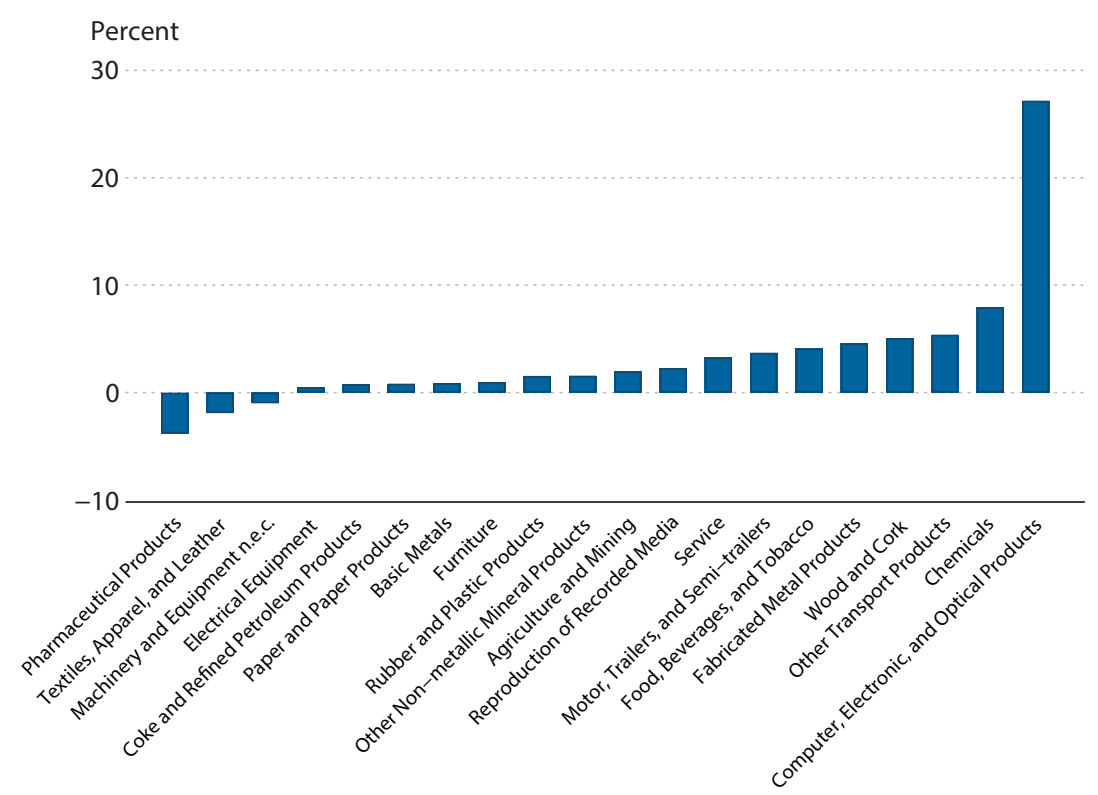

NOTE: Figure reports data for 20 industries, averaged across 42 countries (excluding ROW), for 2000-14.

Similarly, for the average country, the industries that experienced the highest average productivity growth rates are other transport products; chemicals; and computer, electronic, and optical products. In contrast, the industries that experienced the lowest average productivity growth rates are pharmaceutical products; textiles, apparel, and leather; and machinery and equipment n.e.c. (Figure 3 ).

Figure 4 shows the evolution of the average productivity (in logs) for a subsample of countries (left panel) and a subsample of industries (right panel). To compute the average productivity at the country level, we take the average across all the industries in the sample. Similarly, to compute the average productivity at the industry level, we take the average across all the countries in the sample. The left panel shows that the United States has the highest level of productivity, and the growth rate has been roughly constant during the period of analysis. Canada and the United Kingdom are very close to the United States in their levels of productivity, and we do observe some convergence, especially during the second half of the sample period. However, their growth rates of productivity have been very similar to those of the United States. China and Indonesia are lagging behind the United States, and they have experienced rapid convergence to the technology frontier. Indeed, their growth rates are faster than those countries with productivity levels that are closer to the United States. The right panel of Figure 4 reports the evolution of average productivity (in logs) for four industries: computer, electronic, and optical products; chemicals; textiles, apparel, and leather; and paper and paper products. The industry with the largest average productivity is computer, electronic, and 


\section{Figure 4}

\section{Evolution of Average Productivity, 2000-14}
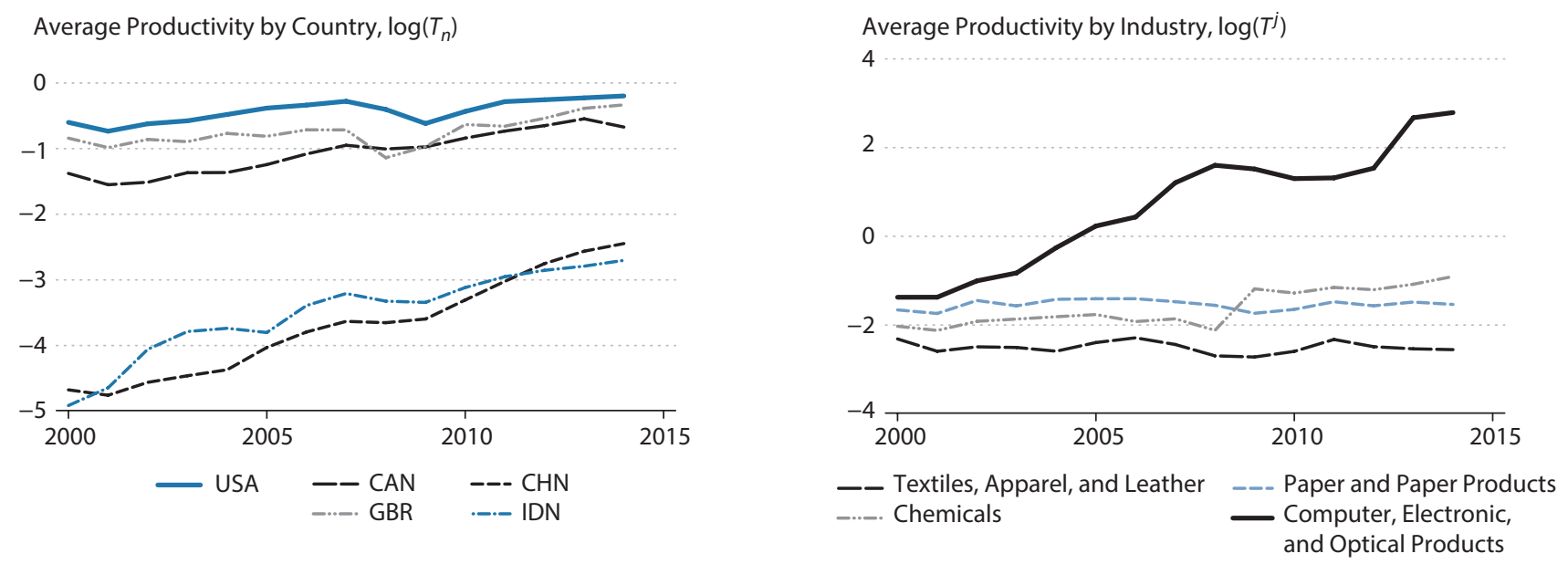

optical products, and its growth rate has been the fastest over the period of analysis. Lagging behind are the remaining industries. Textiles, apparel, and leather and paper and paper products have lower levels of productivity and low growth rates. Chemicals seem to be converging slowly to the levels of productivity of computer, electronic, and optical products, especially during the second half of the sample period.

\section{QUANTIFYING THE SOURCES OF COMPARATIVE ADVANTAGE: THE ROLE OF INNOVATION AND TECHNOLOGY DIFFUSION}

\subsection{Motivation}

Analyzing the driving forces of productivity is important in understanding the sources of comparative advantage. We analyze, quantitatively, the effect that domestic innovation and the adoption of foreign technologies have on the growth of productivity at the countryindustry level. The idea behind this analysis is that countries and industries that invest more resources in innovation can expand the technological frontier and grow (Romer, 1990). However, innovative activity is concentrated in very few, very rich countries. According to OECD data, the United States, South Korea, Japan, and Germany account for the majority of global R\&D. These "leaders" are expanding the technology frontier. Countries farther behind the technology frontier, "followers," can also grow by adopting technology from the leaders. Several economists have argued that the transfer of technology and knowledge from leader to follower countries is an important source of economic growth for the latter (Rosenberg, 1983) presumably leading to productivity growth. $\underline{3}$ Therefore, both innovation and technology transfer can drive productivity growth (Santacreu, 2017). 
Table 1

Productivity Growth from Innovation and Diffusion

\begin{tabular}{lccc}
$\Delta \log T_{n t}^{j}$ & Full sample & Lower income & Higher income \\
\hline $\log \left(\frac{R \& D_{n t}^{j}}{V A_{n t}^{j}}\right)$ & $\begin{array}{c}0.317^{* * * *} \\
(0.093)\end{array}$ & $\begin{array}{c}0.214 \\
(0.138)\end{array}$ & $0.492^{* * *}$ \\
$\log \left(\frac{T_{U S, 2000}^{j}}{T_{n, 2000}^{j}}\right)$ & $\begin{array}{c}0.692^{* * *} \\
(0.128)\end{array}$ & $\begin{array}{c}0.849^{* * *} \\
(0.205)\end{array}$ & $0.766^{* * *}$ \\
Observations & 6,581 & 2,901 & $(0.233)$ \\
$R^{2}$ & 0.006 & 0.007 & 3,125 \\
NOTE: Standard errors are in parentheses. ${ }^{*} p<0.05,{ }^{* *} p<0.01,{ }^{* * *} p<0.001$. & 0.008 \\
countries, 20 industries, and years 2003-14.
\end{tabular}

In this section we study the role of these two sources of productivity growth in two ways. First, we regress the growth rate of our measure of country-industry productivity obtained from the gravity analysis on a measure of both domestic innovation and the potential for technology transfer. Second, we compute a measure of the speed of convergence of a countryindustry to the technology frontier and regress it on the relative R\&D spending of that countryindustry with respect to that industry in the United States (i.e., the technology frontier) and the distance of that country-industry to the frontier.

\subsection{Quantitative Results}

We measure domestic innovation within each country and industry using data on total business R\&D spending, and we measure potential technology adoption as the gap in the level of productivity between each country-industry and that industry in the United States in the initial period (year 2000). In this analysis, we narrow down our sample of countries to those that have available R\&D data at the industry level. With respect to the previous section, we lose 13 countries ( 12 countries and the rest of the world) that do not report data on R\&D at the industry level for the sample of analysis. These countries include Bulgaria, Brazil, Cyprus, Greece, Croatia, Indonesia, India, Lithuania, Luxembourg, Latvia, Malta, and Russia.

Table 1 reports the results. We find that, for the entire sample of countries (first column of Table 1), both domestic innovation and the distance to the technology frontier have a positive and statistically significant effect on productivity growth. In particular, a 1 percent increase in the log of domestic innovation in a country-industry increases its productivity growth by 0.31 percent, and a 1 percent increase in the potential for technology adoption increases productivity growth by 0.69 percent.

We then split the sample of countries into higher-income and lower-income countries. 4 Higher-income countries are closer to the technology frontier, and we would expect them to benefit more from domestic innovation than lower-income countries. Indeed, in the data, there is a strong positive correlation between the level of income per capita of countries and their investment in R\&D. Lower-income countries that are farther away from the technology 
frontier, however, benefit more from adoption of foreign innovations, as it has been quantified in Santacreu (2015). We conduct the same regression analysis as before for each group of countries and industries. Our findings suggest that, in lower-income countries (second column of Table 1), the effect of domestic R\&D on productivity growth is lower than that in higherincome countries (third column of Table 1). In particular, a 1 percent increase in the domestic $\mathrm{R} \& \mathrm{D}$ (in logs) implies a 0.21 percent increase in productivity growth in lower-income countries and a 0.49 percent increase in productivity in higher-income countries. Furthermore, the relative importance of innovation with respect to technology adoption is larger in higherincome countries than in lower-income countries. That is, when we look at the beta coefficients corresponding to domestic innovation and technology diffusion in the regression, we find that the effect of innovation is 0.93 times larger than that of technology diffusion for higherincome countries and 0.38 times larger for lower-income countries.

Finally, we compute a measure of the speed of convergence to the technology frontier. To do that, we first calculate the distance of a particular country-industry with respect to the same industry in the United States (i.e., the technology frontier) as

$$
\operatorname{dist}_{n}^{j}=\left|\frac{T_{U S}^{j}}{T_{n}^{j}}-1\right| .
$$

The growth rate of that measure represents the speed of convergence of country $n$ and industry $j$. We then regress the speed of convergence on the ratio of $R \& D$ spending in country $n$ and industry $j$ relative to the R\&D spending in the United States in that industry $j$ and on our measure of the potential for technology adoption that we used before (Table 2). $\underline{5}$ We find that those countries and industries that are investing more in $\mathrm{R} \& \mathrm{D}$ relative to the United States are closer to the technology frontier. Those countries that have a higher potential to adopt technologies (i.e., are farther away from the technology frontier) close the gap faster.

Our results confirm that both $R \& D$ and technology transfer are key determinants of productivity growth and convergence to the frontier. Hence, they are sources of comparative advantage.

\section{Table 2}

\section{Speed of Convergence from Innovation and Diffusion}

$\begin{array}{lc} & \begin{array}{c}\text { Speed of convergence } \\ \log \left(\frac{R \& D_{n, t}^{j}}{R \& D_{U S, t}^{j}}\right)\end{array} \\ \begin{array}{l}2.099^{* * * *} \\ (0.379)\end{array} \\ \log \left(\frac{T_{U S, 2000}^{j}}{T_{n, 2000}^{j}}\right) & \begin{array}{c}9.319^{* * *} \\ (0.677)\end{array} \\ \text { Observations } & 5,795 \\ R^{2} & 0.032 \\ \text { NOTE: Standard errors are in parentheses. } \\ { }^{*} p<0.05,{ }^{* *} p<0.01,{ }^{* * *} p<0.001 . \text { Results are for } \\ 30 \text { countries, 20 industries, and years 2003-14. }\end{array}$

\section{CONCLUSION}

Understanding the sources of comparative advantage in a country is important in analyzing welfare gains from trade liberalizations. Differences in productivity across countries and industries drive the patterns of international trade and comparative advantage. Hence, iden- 
tifying the sources of these differences is key to evaluating welfare. In this article, we have shown that domestic innovation and international technology diffusion are important sources of productivity growth and comparative advantage of a country.

We have implemented a methodology to determine differences in country-industry productivity from bilateral trade data. We departed from the standard model in that we allowed productivity to vary over time so that our estimation procedure delivered a time series of country-industry productivity. We then analyzed the sources of productivity and comparative advantage. Our results have shown that domestic innovation and the adoption of foreign innovations have a positive and statistically significant effect on the growth rate of productivity and on the speed of convergence at the country and industry level. Therefore, innovation and international technology diffusion appear to be important determinants of comparative advantage. Our reduced-form results are consistent with structural models that have studied the role of innovation and technology adoption as sources of productivity growth and comparative advantage, such as Cai et al. (2017) and Santacreu (2015).

\section{APPENDIX A}

\section{Lists of Industries and Countries}

\section{Table A1}

\section{List of Industries}

\begin{tabular}{lcc} 
Sector & ISIC (Rev. 4) & WIOD (RNr) \\
\hline Agriculture and mining & A-B & $1-4$ \\
Food, beverages, and tobacco & C10, C11, C12 & 5 \\
Textiles, apparel, and leather & C13, C14, C15 & 6 \\
Wood and cork & C16 & 7 \\
Paper and paper products & C17 & 8 \\
Reproduction of recorded media & C18 & 9 \\
Coke and refined petroleum products & C19 & 10 \\
Chemicals & C20 & 11 \\
Pharmaceutical products & C21 & 12 \\
Rubber and plastic products & C22 & 13 \\
Other non-metallic mineral products & C23 & 14 \\
Basic metals & C24 & 15 \\
Fabricated metal products & C25 & 16 \\
Computer, electronic, and optical products & C26 & 17 \\
Electrical equipment & C27 & 18 \\
Machinery and equipment n.e.c. & C28 & 19 \\
Motor, trailers, and semi-trailers & C29 & 20 \\
Other transport products & C30 & 21 \\
Furniture & C31 & 22 \\
Service & C32-U & $23-56$
\end{tabular}

NOTE: ISIC, International Standard Industrial Classification; WIOD, World Input-Output Database. 


\section{Table A2}

List of Countries

\begin{tabular}{|c|c|}
\hline Country name & ISO code \\
\hline Australia\# & AUS \\
\hline Austria\# & AUT \\
\hline Belgium\# & BEL \\
\hline Bulgaria* & BGR \\
\hline Brazil $^{*}$ & BRA \\
\hline Canada\# & CAN \\
\hline Switzerland\# & $\mathrm{CHE}$ \\
\hline China & $\mathrm{CHN}$ \\
\hline Cyprus* & CYP \\
\hline Czech Republic & CZE \\
\hline Germany\# & DEU \\
\hline Denmark\# & DNK \\
\hline Spain & ESP \\
\hline Estonia & EST \\
\hline Finland\# & FIN \\
\hline France\# & FRA \\
\hline United Kingdom\# & GBR \\
\hline Greece* $^{*}$ & GRC \\
\hline Croatia* & HRV \\
\hline Hungary & HUN \\
\hline Indonesia* & IDN \\
\hline India* & IND \\
\hline Ireland\# & IRL \\
\hline Italy & ITA \\
\hline Japan\# & JPN \\
\hline Korea & KOR \\
\hline Lithuania* & LTU \\
\hline Luxembourg* & LUX \\
\hline Latvia* & LVA \\
\hline Mexico & MEX \\
\hline Malta* & MLT \\
\hline Netherland\# & NLD \\
\hline Norway\# & NOR \\
\hline Poland & $\mathrm{POL}$ \\
\hline Portugal & PRT \\
\hline Romania & ROU \\
\hline Russia* & RUS \\
\hline Slovakia & SVK \\
\hline Slovenia & SVN \\
\hline Sweden\# & SWE \\
\hline Turkey & TUR \\
\hline United States\# & USA \\
\hline Rest of the World* & ROW \\
\hline
\end{tabular}




\section{APPENDIX B}

\section{Data Sources}

\section{Table B1}

\section{Original Data and Sources}

\begin{tabular}{|c|c|c|c|}
\hline Variables & Sources & Time & Units \\
\hline$\gamma^{j}$ and $\gamma^{j k}$ & World input-output tables & 2005 & USD (current, millions) \\
\hline Trade volume & WIOD, release 2016 & 2000-14 & USD (current, millions) \\
\hline Labor compensation (\% GDP) & Number employed & 2000-14 & $\%$, millions \\
\hline GDP, conversion factor, deflator & World Bank & $2000-14$ & NA \\
\hline Average annual wages & OECD & 2000-14 & Constant 2016 USD \\
\hline Business enterprise R\&D (ANBERD) & OECD & 2000-14 & PPP, constant 2010 USD \\
\hline Industry codes & Census-NAICS & NA & NA \\
\hline$Z_{U S}^{j}$ & NBER-CES manufacturing & $2000-11$ & NA \\
\hline \multicolumn{4}{|c|}{$\begin{array}{l}\text { NOTE: WIOD, World Input-Output Database; OECD, Organisation for Economic Co-operation and Development; } \\
\text { ANBERD, Analytical Business Enterprise Research and Development; PPP, purchasing power parity; NAICS, North } \\
\text { American Industry Classification System; NBER-CES, National Bureau of Economic Research Manufacturing Industry } \\
\text { Database. }\end{array}$} \\
\hline
\end{tabular}

\section{Bilateral Trade Shares and Value Added}

- We use 2000-14 data from WIOD, released in 2016, and the GDP deflator to convert all data to units of constant 2016 USD.

- We replace trade value with 0.001 if below 0.000001 .

- $X_{n i}^{j}$ is the sum across all importing intermediate industry trade values for each importerexporter industry in one year.

- $X_{n n}^{j}$ is the sum across all importing intermediate industry trade values for each countryindustry from that country.

- We compute $\frac{X_{n i}^{j}}{X_{n n}^{j}}$ and create $\log \left(\frac{X_{n i}^{j}}{X_{n n}^{j}}\right) \cdot X_{n}^{j}=$ total output (“TOT”) of row country-
industry.

- Value added: We take the value added from the WIOD dataset.

- CEPII_distances measures: We use the "CEPII" dataset, which contains geographic variables between country pairs.

\section{Wages}

- We use variable share-of-labor compensation in GDP ("labsh") and total employment (“emp," in millions) from Penn World Table version 9.0. We also use variable GDP (local currency unit), PPP conversion factor as the exchange rate, and GDP deflator from World Bank. 
- We calculate average annual wages $=\frac{\text { Labor Share }{ }^{\star} \mathrm{GDP}}{\mathrm{empl}^{\star} 1,000,000}$ and then convert them to USD and use the GDP deflator to convert the annual wages in units of constant 2016 USD.

\section{Total Factor Productivity}

- We take the variable 4-factor TFP Index, $1987=1.00$ ("tfp4") from the NBER-CES manufacturing database as $Z_{U S}^{j}$. Convert 1987 SIC industries to 2002 NAICS, then to 2007 NAICS, then to ISIC Rev. 4, and then group to match the industries, following Table A1.

- Since the NBER-CES dataset only has period 2000-11, we take the compounded annual growth rate for each industry in the United States and generate $T_{U S}^{j}(2012), T_{U S}^{j}(2013)$, and $T_{U S}^{j}(2014)$ by assuming growth rate doesn't change.

$R \& D$

- We use business R\&D spending (main activity) data (PPP USD, 2010 prices) from ANBERD, among 36 available countries; 30 correspond to the 42 individual countries from WIOD (Table A2).

- We interpolate R\&D using value-added data to fill in missing values.

\section{Calibration of $\gamma^{j}$ and $\gamma^{j k}$}

- We use the WIOD dataset for year 2005 data.

- We remove "ROW" and "TWN" within the entire dataset. We also remove non-intermediate industry-specific column variables ("final").

- We adjust intermediate inputs of column industry $j$ : INT $=\sum$ each intermediate input - VADD - OUTPUT.

- We adjust gross production of column industry $j$ : OUTPUT $=$ INT + VADD.

- $\gamma^{j}=\frac{\text { VADD }}{\text { OUTPUT }} ; \gamma^{j k}=1-\gamma^{j} * \frac{\sum \text { each intm. inputs }}{\text { INT }}$. We verify that $\gamma^{j}+\sum_{j} \gamma^{j k}=1$.

- We set $\gamma^{j}=0$ and $\gamma^{j k}=0$ when it is a missing value due to zero "OUTPUT" value. 


\section{Santacreu and Zhu}

\section{NOTES}

1 The notations in this article are such that every time there are two subscripts or two superscripts, the one on the right corresponds to the source country and the one on the left corresponds to the destination country.

$\underline{2}$ The lists of industries and countries are reported in Appendix A. The data and the calibration of $\gamma^{j}$ and $\gamma^{j k}$ are documented in detail in Appendix B. Throughout our analysis we assume that $\theta$ is common across countries and industries and set it equal to 4, as it is standard in trade (Waugh, 2010).

3 Transfer of knowledge can occur through imported technology (Coe et al., 1997, Keller, 2004, and Santacreu, 2015) and multinational activity (Burstein and Monge-Naranjo, 2009, and Guadalupe et al., 2012), among other channels.

4 We take the average of 2005 GDP per capita data (USD) of our 30 sample countries, define those with higher-thanaverage GDP per capita as higher-income countries, and define the rest as lower-income countries. See Appendix A for details.

$\underline{5}$ We drop those observations for which productivity is larger than in the United States (5 percent of the observations).

\section{REFERENCES}

Barro, R. and Sala-i-Martin, X. "Technological Diffusion, Convergence, and Growth." Journal of Economic Growth, March 1997, 2(1), pp. 1-26; https://doi.org/10.1023/A:1009746629269.

Burstein, A. and Monge-Naranjo, A. "Foreign Know-How, Firm Control, and the Income of Developing Countries." Quarterly Journal of Economics, February 2009, 124(1), pp. 149-195; https://doi.org/10.1162/qjec.2009.124.1.149.

Cai, J.; Li, N. and Santacreu, A. "Knowledge Diffusion, Trade and Innovation across Countries and Sectors." Working Paper 2017-029A, Federal Reserve Bank of St. Louis, 2017; https://research.stlouisfed.org/wp/more/2017-029.

Caliendo, L. and Parro, F. "Estimates of the Trade and Welfare Effects of NAFTA." Review of Economic Studies, 2015, 82(1), pp.1-44; https://doi.org/10.1093/restud/rdu035.

Coe, D.; Helpman, E. and Hoffmaister, A. “North-South R\&D Spillovers.” Economic Journal, January 1997, 107(440), pp. 134-149; https://doi.org/10.1111/1468-0297.00146.

Costinot, A.; Donaldson, D. and Komunjer, I. "What Goods do Countries Trade? A Quantitative Exploration of Ricardo's Ideas." Review of Economic Studies, 2012, 79(2), pp. 581-608; https://doi.org/10.1093/restud/rdr033.

Eaton, J. and Kortum, S. “Technology, Geography, and Trade.” Econometrica, September 2002, 70(5), pp. 1741-1779; https://doi.org/10.1111/1468-0262.00352.

Ethier, W. “Dumping." Journal of Political Economy, June 1982, 90(3), pp. 487-506; https://doi.org/10.1086/261071.

Finicelli, A.; Pagano, P. and Sbracia, M. "Ricardian Selection." Journal of International Economics, 2013, 89(1), pp. 96-109; https://ideas.repec.org/a/eee/inecon/v89y2013i1p96-109.html.

Grossman, G. and Helpman, E. Innovation and Growth in the World Economy. Cambridge: MIT Press, 1991a; https://mitpress.mit.edu/books/innovation-and-growth-global-economy.

Grossman, G. and Helpman, E. "Trade, Knowledge Spillovers, and Growth." European Economic Review, 1991b, 35, pp. 517-526; https://doi.org/10.1016/0014-2921(91)90153-A.

Guadalupe, M.; Kuzmina, O. and Thomas, C. "Innovation and Foreign Ownership." American Economic Review, December 2012, 102(7), pp. 3594-3627; https://doi.org/10.1257/aer.102.7.3594.

Keller, W. "International Technology Diffusion." American Economic Review, September 2004, 42(3), pp. 752-782; https://doi.org/10.1257/0022051042177685.

Levchenko, A. and Zhang, J. "The Evolution of Comparative Advantage: Measurement and Welfare Implications." Journal of Monetary Economics, 2016, 78(c), pp. 96-111; https://doi.org/10.1016/j.jmoneco.2016.01.005.

Proudman, J. and Redding, S. "Evolving Patterns of International Trade." Review of International Economics, August 2000, 8(3), pp. 373-396; https://doi.org/10.1111/1467-9396.00229. 
Rivera-Batiz, L. and Romer, P. “Economic Integration and Endogenous Growth." Quarterly Journal of Economics, May 1991, 106(2), pp. 531-555; https://doi.org/10.2307/2937946.

Romer, P. “Endogenous Technological Change." Journal of Political Economy, 1990, 98(5, Part 2), pp. S71-S102; https://doi.org/10.1086/261725.

Rosenberg, N. Inside the Black Box: Technology and Economics. Cambridge: Cambridge University Press. January 1983; http://www.cambridge.org/us/academic/subjects/economics/industrial-economics/inside-black-box-technology-and-economics?format=PB\&isbn=9780521273671\#gpdavvWflwuclm20.97.

Sampson, T. "The Global Productivity Distribution and Ricardian Comparative Advantage." May 2017; https://www.princeton.edu/ ies/IESWorkshopS2017/SampsonPaper.pdf.

Santacreu, A. "Innovation, Diffusion, and Trade: Theory and Measurement." Journal of Monetary Economics, October 2015, 75, pp. 1-20; https://doi.org/10.1016/j.jmoneco.2015.06.008.

Santacreu, A. "Convergence in Productivity, R\&D Intensity, and Technology Adoption." Federal Reserve Bank of St. Louis Economic Synopses, 2017, No. 11; https://doi.org/10.20955/es.2017.11.

Somale, M. "Comparative Advantage in Innovation and Production." International Finance, Discussion Papers 1206, 2017; https://doi.org/10.17016/IFDP.2017.1206.

Waugh, M. "International Trade and Income Differences." American Economic Review, December 2010, 100(5), pp. 2093-2124; https://doi.org/10.1257/aer.100.5.2093. 
